\title{
THERMAL REGIME OF A SURGE-TYPE GLACIER
}

\section{By Robert BindsGhadler}

(Geophysics Program, University of Washington, Seattle, Washington 98195, U.S.A.)

William D. Harrison

(Geophysical Institute, University of Alaska, Fairbanks, Alaska 997o I, U.S.A.)

Charles F. Raymond and Claude Gantet

(Geophysics Program, University of Washington, Seattle, Washington 98195, U.S.A.)

Abstract. Recent measurements of near-surface temperature and surface velocity from the Variegated Glacier are presented. Temperature was measured with thermocouples at nine sites spaced along the length of the glacier. Maximum measurement depths ranged from $8 \mathrm{~m}$ in the lower ablation area to $20 \mathrm{~m}$ in the accumulation area. Accuracy of measurement was about 0.1 deg. By the end of summer the temperature at all measured sites and depths was not measurably different from zero, indicating that practically all of the near-surface ice of the glacier is temperate. The distribution of surface velocity along the length of the glacier shows distinct variations with time which cannot be explained by internal deformation in the glacier as influenced by changes in ice depth and slope. This indicates that the glacier is sliding over much of its length, which requires that the base of the glacier is temperate. Taken together, the near-surface temperature and velocity data provide good evidence that Variegated Glacier is temperate throughout and also indicate that the surge behavior of this glacier cannot be explained by thermal triggering.

RÉsumé. Régime thermique d'un glacier du type à crues rapides. On présente de récentes mesures de températures près de la surface, et de vitesse superficielle sur le Variegated Glacier. Les températures étaient mesurées par thermocouples en neuf points espacés le long de l'axe du glacier.

Les profondeurs maximum des mesures allaient de $8 \mathrm{~m}$ dans le bas de la zone d'ablation, à $20 \mathrm{~m}$ dans la zone d'accumulation. La précision des mesures était d'environ o, I deg. A la fin de l'été, les températures dans tous les points de mesure et à toutes les profondeurs n'étaient pas, de manière mesurable, différentes de $0^{\circ} \mathrm{C}$, ce qui prouve que pratiquement toute la glace proche de la surface du glacier est tempérée. La distribution de la vitesse à la surface le long de l'axe du glacier montre des variations nettes avec le temps, qui ne peuvent s'expliquer par des déformations internes dans le glacier, liées à des changements de profondeur de glace et de pente. Ceci prouve que le glacier glisse sur la plus grande partie de sa longueur, ce qui implique que la base du glacier est tempérée. Prises dans leur ensemble, les données de température et de vitesse près de la surface, apportent une preuve valable que le Variegated Glacier est entièrement tempéré et indiquent également que le comportement de crue de ce glacier ne peut être expliqué par un mécanisme thermique de déclenchement.

Zusammenfassung. Warmehaushalt eines zu Ausbrüchen neigenden Gletschers. Es wird über Messungen der oberflächennahen Temperatur und der Oberflächengeschwindigkeit am Variegated Glacier berichtet. Die Temperatur wurde an neun Stellen längs der Gletscherachse mit Thermoelementen gemessen. Die maximale Messtiefe reichte von $8 \mathrm{~m}$ in der unteren Ablationszone bis $20 \mathrm{~m}$ im Nährgebiet. Die Messgenauigkeit betrug etwa o, I deg. Am Ende des Sommers konnte an keiner Messtelle und in keiner Tiefe eine von $0^{\circ} \mathrm{C}$ verschiedene Temperatur festgestellt werden, was darauf hinweist, dass praktisch das gesamte oberflächennahe Eis des Gletschers temperiert ist. Die Verteilung der Oberflächengeschwindigkeit längs des Gletschers zeigt deutliche seitliche Schwankungen, die nicht durch innere Verformung im Gletscher unter dem Einfluss von Eisdicken- und Gefällsänderungen erklärt werden können. Dies deutet darauf hin, dass der Gletscher weitgehend auf seinem Bett gleitet, was nur möglich ist, wenn er am Untergrund temperiert ist. Insgesamt liefern die oberflächennahen Temperaturen und Geschwindigkeiten den klaren Beweis, dass der Variegated Glacier durch und durch temperiert ist; sie lassen ausserdem darauf schliessen, dass das Ausbruchsverhalten dieses Gletschers nicht durch thermische Vorgänge ausgelöst wird.

\section{INTRODUCTION}

One possible explanation of periodic surges of glaciers depends on an oscillation between periods of sub-freezing basal temperature during which there is no sliding and periods with melting conditions accompanied by rapid sliding (Robin, 1955; Hoffmann and Clarke, I973). Measurements of temperature profiles in Rusty and Trapridge Glaciers in the Yukon Territory have shown that this mechanism might explain surges of sub-polar glaciers in the relatively cold continental climate of this area (Classen and Clarke, I97 I). However, this mechanism would not be able to explain surges in glaciers which are continuously warm at their bases, such as would be expected in temperate glaciers. 
Post (1969) pointed out that surging glaciers exist in a variety of environments including maritime conditions and he suspected that some surging glaciers are temperate. However, the existence of a temperate surging glacier has not yet been thoroughly verified by temperature measurements. Near-surface temperature measurements on the surge-type Black Rapids Glacier suggest that it may be temperate at depth (Harrison and others, I975). Some reconnaissance measurements of late summer firn temperature by Harrison (1972) on the surge-type Variegated Glacier provided some indication that it is temperate, as originally suggested by Post (1969). This paper presents more comprehensive measurements of near-surface temperature and velocity made on the Variegated Glacier, which provide convincing evidence that it is a temperate glacier and argue against initiation of surges on this glacier by a simple transition from a zero sliding condition to one of sliding.

Variegated Glacier lies $55 \mathrm{~km}$ north-north-east of Yakutat, Alaska. It has a well documented history of spectacular surges with a fairly regular period of about 20 years, the last surge occurring in 1964 and 1965 (Post, I969). The glacier runs from east to west with a relatively uniform slope of about $5^{\circ}$ for a distance of about $20 \mathrm{~km}$ from its head at $\mathrm{I} 950 \mathrm{~m}$ to nearly reach tide water at the junction of Russell Fjord and Disenchantment Bay. Figure I gives a map of the glacier showing the location of surface movement markers, temperature measurement sites, and triangulation stations around the margin.

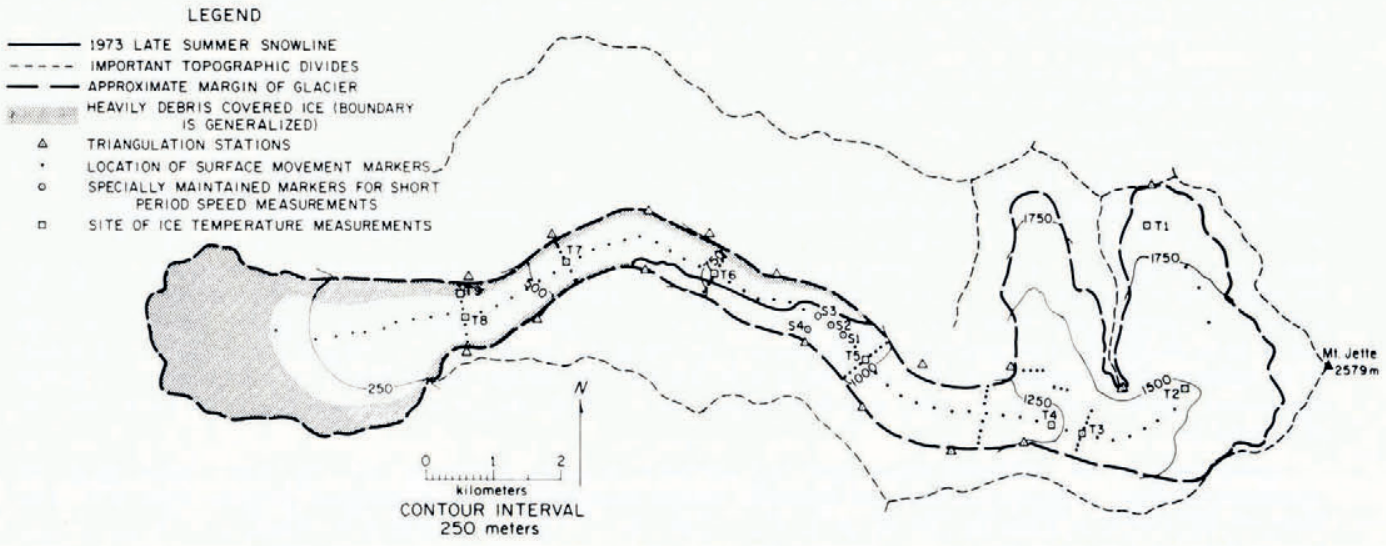

Fig. I. Map of Variegated Glacier.

\section{Near-Surface temperature measurements}

Near-surface ice temperature was measured at the nine sites shown in Figure I. Thermocouples spaced at 3 or $4 \mathrm{~m}$ depth intervals were placed in holes steam-drilled into the ice or firn. Readings of the copper-constantan thermocouples were made with a thermocouple potentiometer of I to $2 \mu \mathrm{V}$ sensitivity and a reference bath of snow saturated with snow melt water giving an accuracy of slightly better than 0 . I deg.

During the early summer of I973, the warming of the previous winter's snow and the underlying firn was examined at site Ti lying at the very head of the glacier at an elevation about I $800 \mathrm{~m}$. Table I shows the history of thermocouple placement and readings at this site. The measurements indicate a fairly rapid warming of the snow and firn probably by freezing of downward percolating water. In order to reduce effects of abnormal percolation caused by the steam drill holes, snow was sifted and packed into them on initial placement of the thermocouples. The bulk of the material down to $17 \mathrm{~m}$ was apparently at the melting point by 8 July. It is likely that the slightly sub-freezing material at $9 \mathrm{~m}$ on this date was warmed to $0^{\circ} \mathrm{C}$ during the course of the summer. 
Table I. Placement and Readings from thermocouples AT SITE TI DURING I973

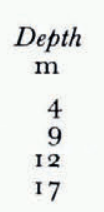

Date of placement
I 5 June
I5 June
27 June
27 June

$\begin{array}{cc}\text { Temperature reading } \\ 27 \text { June } & 8 \text { July } \\ { }^{\circ} \mathrm{C} & { }^{\circ} \mathrm{C} \\ -2 & 0 \\ -1 & -0.4 \\ & 0 \\ & 0\end{array}$

Temperature was read at the remainder of the sites only at the end of summer I974 (Table II). All of the measured temperatures were $0^{\circ} \mathrm{C}$ within the measurement accuracy. One slightly negative temperature of about $-\mathrm{O} . \mathrm{I}^{\circ} \mathrm{C}$ was recorded at site $\mathrm{T} 9$ in ice covered by rocky debris and this might possibly represent a local zone of very slightly sub-freezing ice caused by the rocks as has been observed on the Athabasca Glacier (Paterson, 1972).

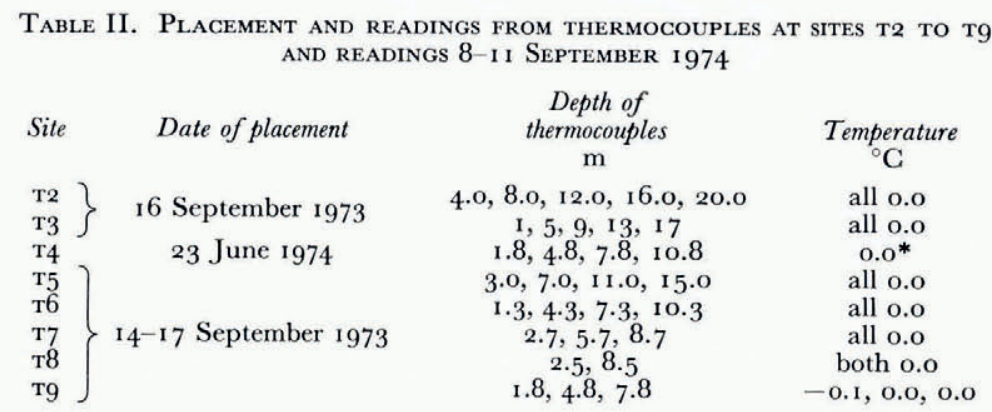

* One thermocouple defective; its identity uncertain.

These observations indicate that practically all the near-surface ice or firn of the glacier is temperate by the end of summer. It is unlikely that a winter cold wave could penetrate below the depths studied, so that over the year 1973-74 the glacier was not cooled from the surface. The slightly sub-freezing temperatures found near the surface in the ablation areas of some otherwise temperate glaciers (e.g. Paterson, 1972; Schytt, 1969) seem to be largely absent here.

\section{Change of surface speed with time}

Markers were arranged in a longitudinal line along the center of the glacier (Fig. I) and could be located by theodolite triangulation from nearby stations. The displacement of a marker over a given time interval gives its average speed, and to a good approximation this represents the average surface speed of the glacier at a point half-way between the initial and final positions of the marker. Figure 2 shows the resulting longitudinal profiles of surface speed measured for several time intervals.

If the glacier is not sliding, standard theory (Nye, I952) and the commonly assumed flow law for ice (Glen, I955) predict a relation between surface velocity $u_{\mathrm{s}}$, ice depth $H$, surface slope $\alpha$, and cross-section shape factor $f$ given by

$$
u_{\mathrm{s}}=\frac{2 A}{n+\mathrm{I}}(f \bar{\rho} g \sin \alpha)^{n} H^{n+1}
$$




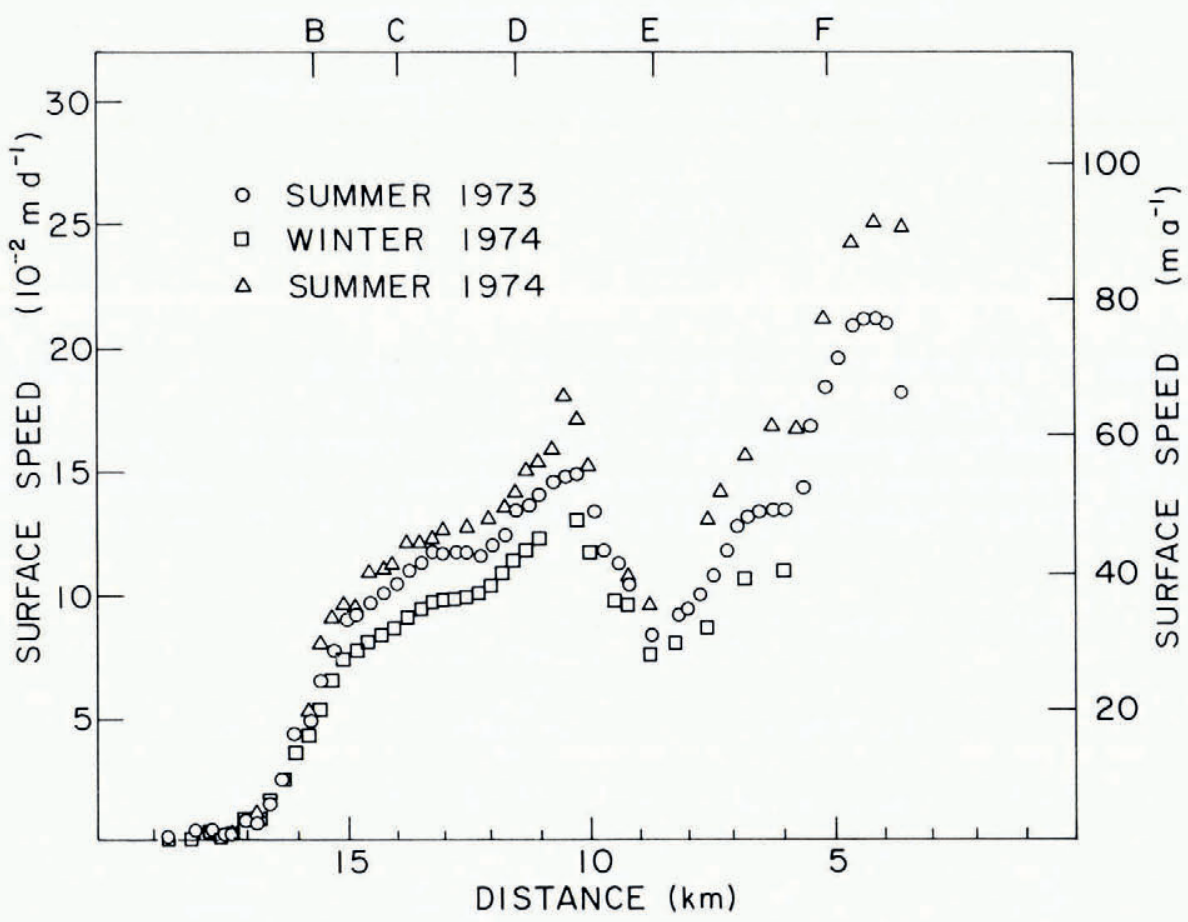

Fig. 2. Average surface speed for the time intervals: Mid-7une 1973 to early September 1973 (summer 1973), early September 1973 to mid-June 1974 (winter 1974), and mid-June 1974 to early September 1974 (summer 1974).

where $g$ is the gravitational acceleration, $\bar{\rho}$ the depth-averaged bulk density, and $A$ and $n$ are the flow-law parameters. The longitudinal profiles of surface and bed elevation are known from the surveying and extensive seismic depth measurements. Shape factors $f$ can be estimated at six positions along the length from seismically determined cross-section shape and the numerical calculations of cross-section flow by Nye (1965). These data are to be presented elsewhere (Bindschadler and others, in preparation) where it will be shown that the observed spatial pattern of velocity is compatible with the predictions of Equation ( $\mathrm{I}$ ) when an effective surface slope $\alpha$ is determined on a length scale of 2 to $4 \mathrm{~km}$ (about 8 to 16 times the average depth of $270 \mathrm{~m})$ and flow-law parameters $\left(A=0.14^{8} \mathrm{bar}^{-4.2} \mathrm{a}^{-1}, n=4.2\right)$ are taken from Glen's results for ice at a temperature of $-0.02{ }^{\circ} \mathrm{C}$ (Glen, I955; Nye, I957). Thus the observed rates of motion can be explained by internal deformation without substantial sliding. However, uncertainty in the flow law, ice depth, and the corrections for lateral and longitudinal stress gradients make it impossible to determine whether the sliding velocity is precisely zero. The variation of velocity with time suggests that the glacier may be sliding, but it is necessary to examine whether the variations could have been caused by changes in depth and slope.

Changes in the surface-elevation profile of the glacier were established by differencing stake elevations against a continuous reference profile of center-line surface elevation represented by 125 control points and interpolation between them. The control points were spaced in order to give a smooth center-line curve approximately following the more irregular longitudinal line of stakes and also to allow local variations in surface slope to be represented. Control elevations were chosen graphically to make the reference profile fit the marker elevations measured in June 1973 to the plotting accuracy of about I m. Results for elevation 
differences are shown in Figure 3. The main source of error arises from uncertainty in the June 1973 profile between the measured stakes, so that the effect of down-slope displacement of a marker cannot be perfectly corrected. Small effects from non-zero lateral slope for stakes lying slightly to the side of the center-line and direct measurement error also contribute. These errors introduce scatter into the data, and possibly there are some real local variations. However, the general pattern of change for each time is apparent and is represented by the smooth curves. The elevation changes do not exceed several per cent of the ice depth, which has a mean value of about $270 \mathrm{~m}$. An exception is the lowest part of the glacier, where the depth is small. The large-scale slope changes are also less than a few per cent.

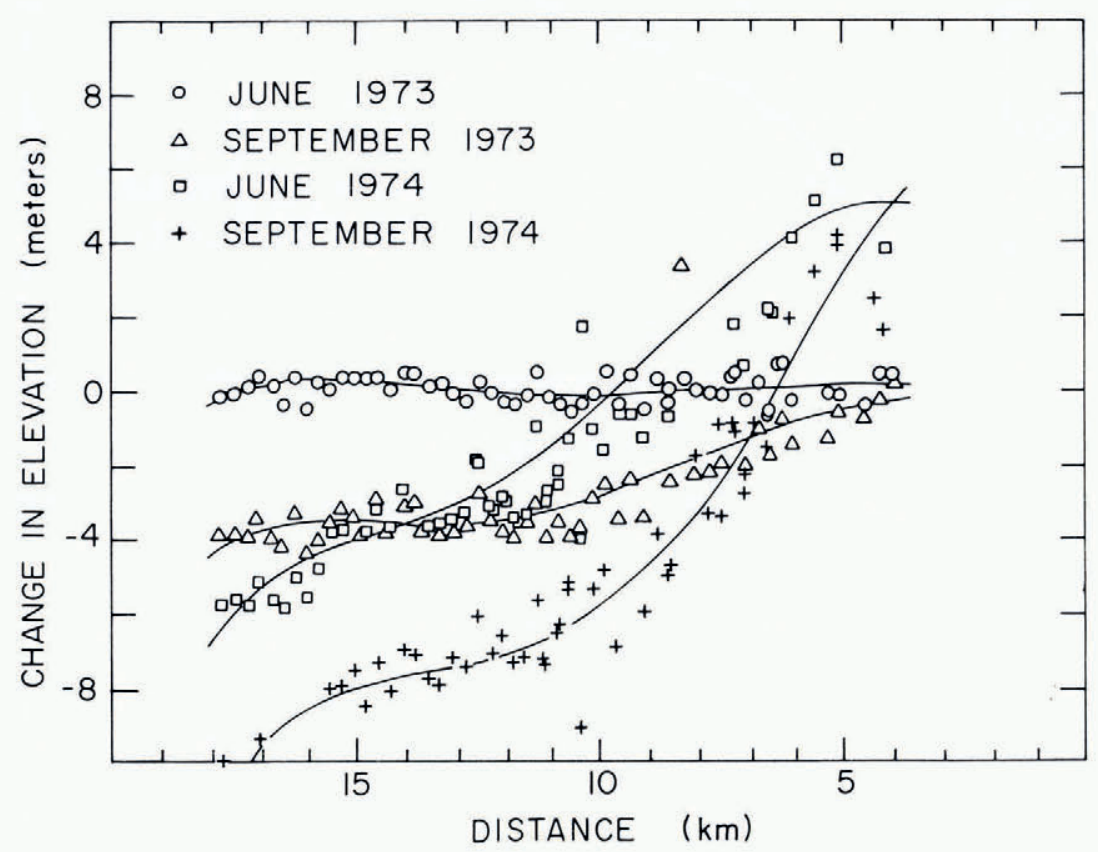

Fig. 3. Surface elevation relative to the reference profile of June 1973.

Theoretical values of average speed over a given time interval were calculated with $H$ and $\alpha$ being computed from the average of the surface-elevation profiles determined at the beginning and end of the time interval. This should be a good approximation for summer during which there is a monotonic decrease in surface level at all elevations. However, it tends to underestimate the average thickness over the winter interval (September to June). Change in internal stress corresponding to the change in thickness profile was computed using the density of glacier ice, thus, in effect, assuming no change of density profile below the surface with time. The resulting theoretical predictions of the fractional change in velocity relative to summer 1973 are shown in Figure 4 for summer 1974 and in Figure 5 for winter 1974 . These can be compared to the observed fractional changes. The theoretical changes in internal deformation are not nearly large enough, and in some places are not even of the right sense, to explain the observed changes in surface speed. The disagreement cannot be explained by the assumptions made in the analysis. The assumption of a fairly large value of $n=4.2$ actually makes the theoretical velocity more sensitive to changes in depth or slope than would be deduced with a more usual value of $n$ about 3 . Also the effect of the assumption 


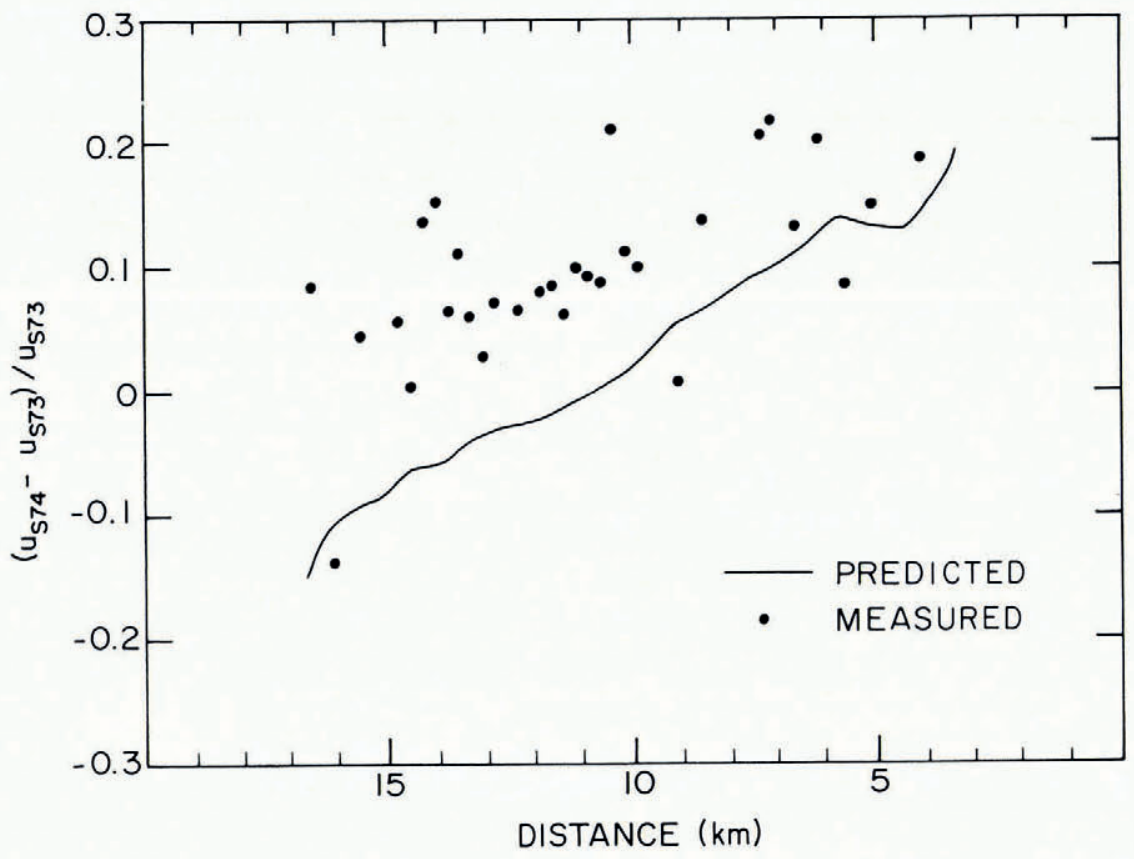

Fig. 4. Fractional change of surface speed for summer 1974 in comparison with summer 1973 as measured and predicted from Equation $(I)$.

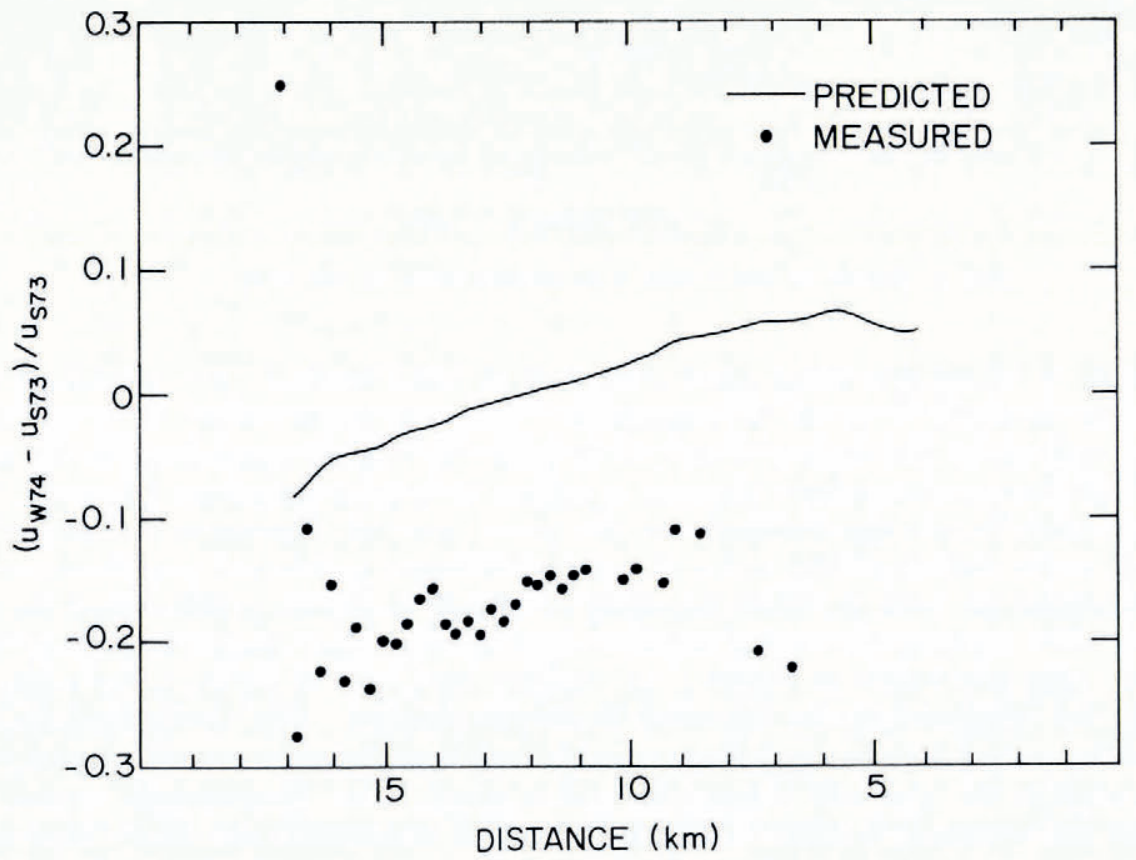

Fig. 5. Fractional change of surface speed for winter 1974 in comparison with summer 1973 as measured and predicted from Equation ( $I$ ). 
concerning the mean winter surface profile tends to produce better agreement between observed and theoretical speed than would be achieved with a more realistic profile. Furthermore, the fractional change in speed is independent of flow-law parameter $A$ and shape factor $f$, assuming they are constant, and also it is quite insensitive to small errors in the actual depth of the glacier.

Additional evidence comes from short-interval measurements of surface speed made over a $17 \mathrm{~d}$ period on four specially maintained stakes lying near the equilibrium line (Fig. 6). Significant loosening of a stake by down-melting of the snow surface and absorption of radiation on the sub-surface part of the stake was prevented by covering the surrounding area with semi-opaque fabric and frequent shovelling of snow around the stake. This procedure, and short lines of sight from triangulation station, gave good accuracy. These stakes

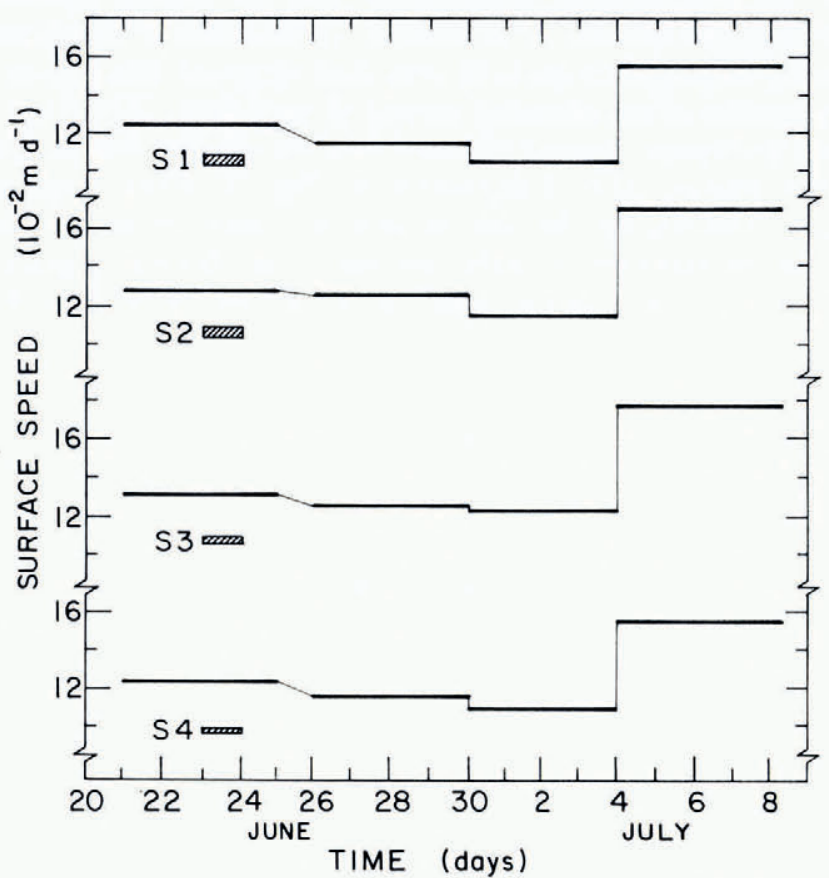

Fig. 6. Surface speed averaged over about 4 d intervals as measured at markers $S_{I}$ to $S_{4}$ during 1974 . Bars show the possible error from the combined effects of surveying and wobbling of the stakes.

were separated by distances of the order of one-half the glacier width (Fig. I), so the coherence of the speed variations indicates that they do not represent local effects of the surface such as crevassing. Furthermore, the surface elevation profile of the glacier was not changing significantly on this short time scale.

The most plausible explanation of the speed variations on all three of the time scales considered above is a variable rate of sliding, such as has been inferred on other glaciers from similar data (e.g. Haefeli, I970; Hodge, 1974). The existence of sliding seems uncertain only in the lower part of the glacier, where the measured velocities are low and approach the measurement error, and in the unmeasured upper parts of the glacier. Based on current theoretical concepts about glacier sliding these observations indicate that the base of the glacier is wet and temperate over most of its length at least during the summer. 


\section{Discussion}

Jarvis and Clarke (1974) have shown that water introduced into a glacier by extensive crevassing during a surge can cause the glacier to be warmer than it would otherwise be. As a result of this process the ice temperature actually decreases with depth at some localities on the Steele Glacier, which surged in $1965-66$ (only one year later than the Variegated Glacier). This opens up the possibility that the Variegated Glacier might be cold at depth even though the near surface is presently temperate. However, if this is to be true, the near-surface temperature would have to be sub-freezing at sometime during the interval between surges. It seems unlikely that substantial cooling could occur within the decade before the next expected surge. Even if surface cooling were to occur during this short time, the heat deficit would probably be erased by the effects of crevasses during the next surge.

Taken together, the near-surface temperature and the sliding behavior provide strong evidence that the Variegated Glacier is temperate. Irrespective of the actual thermal regime, the existence of sliding between surges indicates that surges of this glacier are probably not initiated by the termination of an extended period of no sliding. There is a remote possibility that the unmeasured lowermost several kilometers of the glacier length could be cold, particularly in view of the substantial rock-debris cover (Fig. I). Even if this is true, it does not affect the conclusion concerning the mechanism of surge initiation, since photographic evidence indicates that the fast motion of the last surge started well up glacier and propagated into this zone in the latter phases of the surge (personal communication from A. S. Post).

\section{Acknowledgements}

This work could not have been accomplished without the efforts of the many people who assisted us in the field work and we are grateful for their perseverence. The U.S. Geological Survey and California Institute of Technology generously lent some essential equipment to the project. Gulf Air Taxi, Gay Airways, Navigational Services Incorporated, and Ken Wells provided logistical support, and the U.S. Forest Service and Bureau of Land Management gave permission for work on the glacier. This research was funded by the National Science Foundation under grant numbers GA-36039 and GA-36o4o.

\section{REFERENCES}

Classen, D. F., and Clarke, G. K. C. 1971. Basal hot spot on a surge type glacier. Nature, Vol. 229, No. 5285, p. $48 \mathrm{I}-83$.

Glen, J. W. 1955. The creep of polycrystalline ice. Proceedings of the Royal Society of London, Ser. A, Vol. 288, No. 1175 , p. 519-38.

Haefeli, R. 1970. Changes in the behaviour of the Unteraargletscher in the last 125 years. Fournal of Glaciology, Vol. 9, No. 56, p. 195-212.

Harrison, W. D. 1972. Reconnaissance of Variegated Glacier: thermal regime and surge behavior. Fournal of Glaciology, Vol. I I, No. 63 , p. 455-56. [Letter.]

Harrison, W. D., and others. 1975. Temperature measurements on Black Rapids Glacier, Alaska, 1973, by W. D. Harrison, L. R. Mayo and D. C. Trabant. (In Waller, G., and Bowling, S. A., ed. Climate of the Arctic. Fairbanks, Geophysical Institute, University of Alaska, p. 350-52.)

Hodge, S. M. 1974. Variations in the sliding of a temperate glacier. Journal of Glaciology, Vol. 13, No. 69, p. $349-69$.

Hoffmann, J. W., and Clarke, G. K. C. 1973. Periodic temperature instabilities in sub-polar glaciers. (In [International Hydrological Decade.] The role of snow and ice in hydrology. Proceedings of the Banff symposia, September 1972. Paris, UNESCO; Geneva, WMO; Budapest, IAHS, Vol. 1, p. 445-53.)

Jarvis, G. T., and Clarke, G. K. C. 1974. Thermal effects of crevassing on Steele Glacier, Yukon Territory, Canada. Journal of Glaciology, Vol. 13 , No. 68, p. 243-54.

Nye, J. F. 1952. The mechanics of glacier flow. Journal of Glaciology, Vol. 2, No. 12, p. 82-93.

Nye, J. F. 1957. The distribution of stress and velocity in glaciers and ice-sheets. Proceedings of the Royal Society of London, Ser. A, Vol. 239, No. 12 16, p. I 1 3-33. 
Paterson, W. S. B. 1972. Temperature distribution in the upper layers of the ablation area of Athabasca Glacier, Alberta, Canada. Fournal of Glaciology, Vol. 1 i, No. 61, p. $3^{1-41}$.

Post, A. S. 1969. Distribution of surging glaciers in western North America. Fournal of Glaciology, Vol. 8, No. 53, p. $229-40$.

Robin, G. de Q. 1955. Ice movement and temperature distribution in glaciers and ice sheets. Fournal of Glaciology, Vol. 2, No. 18 , p. $523-32$.

Schytt, V. 1969. Some comments on glacier surges in eastern Svalbard. Canadian Journal of Earth Sciences, Vol. 6 , No. 4 , Pt. 2, p. $867-73$.

\section{DISGUSSION}

M. M. Miller: As a caution towards not putting all our eggs in that proverbial solo basket, perhaps it is worth noting the obvious possibility of load relationship to the sudden and extensive avalanching from the March 1964 Alaska earthquake. I did an air-photo survey of that area in September 1964 and was impressed by the evidences of massive recent avalanches on these glacier surfaces, of increased crevassing and block ruptures in the ice, and of much local fracturing and shattering in the bedrock and glacial drift on the flanks of Disenchantment Bay, Russell Fiord, and Nunatak Fiord. It therefore may not be coincidental that Variegated Glacier, located as it is, was well along in its surge a few months after this major 'quake. But should we also not keep well aware that other "causal factors" too may not be coincidental - and in fact that they may be quite interrelated?

C. F. Raymond: The Variegated Glacier seems to have a regular period, which suggests that the onset of the surges is not affected by the external factors you mention. Your caution to keep an open mind concerning the cause of surge behaviour is good advice for both those doing field and theoretical work.

G. DE Q. Robin: Where does the place where velocity decreases with time lie in relation to the equilibrium line?

RAymond: Our observations have not been continued long enough to establish a trend in the time variation of velocity. The change from summer 1973 to summer 1974 was in general an increase over the full observed length of the glacier. On the other hand, the change from summer 1973 to winter 1974 represents a decrease everywhere observations were made.

Miller: Regarding your surface elevation-change analyses in 1973 and I974, to what extent have you taken into account the surface ablation effects over the melt season? These can be of a magnitude of tens of meters during a summer season on the lower reaches of glaciers in that maritime sector of Alaska.

RAYMOND: We made direct measurement of surface elevation by triangulation from stations on the valley sides. Ablation and vertical motions were also measured and are reported elsewhere. 